\title{
Role of Negotiation in the Completion of Conflict: An Theoretical Perspective
}

\author{
Patrice Lumumba ${ }^{1}$, Husain Abdullah ${ }^{2}$ \\ ${ }^{1}$ Department of International Relations. Faculty of Social Science and Political Science. University of Hasanuddin. Indonesia \\ ${ }^{2}$ Department of International Relations. Faculty of Social Science and Political Science. University of Hasanuddin. Indonesia
}

\begin{abstract}
Negotiation is an instrument or tool in making an interaction each other, where internally in the human personality act as the negotiator or even externally who involving any actors in order to obtain specific goals. In the implementation, negotiation is not an instant way to get or having any limitation time, but will be proceed in time until it is reaching the goals by struggled through the step by step and its mechanism. These conflict phenomenom have been an existing thing at the very beginning of human life which continuously happening and developing in the limitless time, whether it is conflict between state with state or non-state actor with nonstate actor. Negotiation become the options in solving a conflict because assumed as the good step, where the conflicted actors able to meet together and seeking the solutions of faced problems.
\end{abstract}

Keywords: Negotiation, Conflict, Completion, Theoretic, Role

\section{Introduction}

This paper aims to explain that negotiation and conflict are two things who keep bringing together and keep exist in the international world. Many facts shows that conflict happening started from the egoistical of state leaders and tend to following up its desire, and explicitly reacted through the violence. These violence treatment replied with the same treatment in which stimulating conflict and war. Many of the phenomenom of conflict and war has been exist in the entire regions of the earth such as Middle East, Africa, Latin America, South Asia, East Asia, South-East Asia, and Middle Europe.

Conflict context in this paper only theoretical, since it speaking about conflict that is not an simple thing. We must pay attention in any complexity things and there exist any aspects who related each other in a conflict. In other words, there is no conflict without two actors or more. The conflicts who exist in the international world generally comes from the past history, whether it involves territorial or natural resources. Another part, complexity of conflict consist of simple thing until the complicated ones, even there exist conflict in years who can't be fixed. Observing historically, conflict exist since the beginning of the humankind. Many interests in the human life enables to make an conflict. Conflict become an phenomenom who could be happened any time, wherever and appears in any community without exception.

\section{Explanation}

\subsection{Negotiation}

Literally, negotiation comes from the terms of latin language "negotiates" who comes from the word "negotiare", which means to do a business. Meanwhile in the mandarin terms, the basic meaning of negotiation "Tan-Pan" which means discussing and deciding, "Hui-Tan" means meeting and discussing.
Terminologically, negotiation defined:

a) Collin Cobuild English Dictionary;

Negotiations are formal discussion between parties having different aims or intention, especially in business or politics, during which they try to reach an agreement.

b) Oxford English Dictionary; Negotiations is to confer with other for the purpose of arranging some matter by mutual agreement.

c) George M Hartmann;

Negotiation is the process of communication by which two parties, each with other own viewpoint and objectives, attempt to reach a mutually satisfactory agreement on a matter of common concern.

d) Howard Raiffa;

Negotiation is one of the many established ways for settling disputes. It is concerned with situations in which two or more parties recognize that difference of interest and values exist among them and in which they want (or are compelled) to seek a compromise agreement through negotiation.

The definition above picturizing that negotiation is a process of settling a problem or dispute. Where in negotiation, every negotiator must be able and wanted to seek for best options creatively to finally find a solution. The involved solution is the solution who benefits two parties.

These things more convinced by Alo Liliweri, that:

"Negotiation is a process who involves two or thre parties to discuss several options of opinion who became the source of conflict, in order to achieve mutual agreement who benefits two parties.

The negotiation process can be picturized below : 


\section{International Journal of Science and Research (IJSR) \\ ISSN (Online): 2319-7064}

Index Copernicus Value (2016): 79.57 | Impact Factor (2015): 6.391

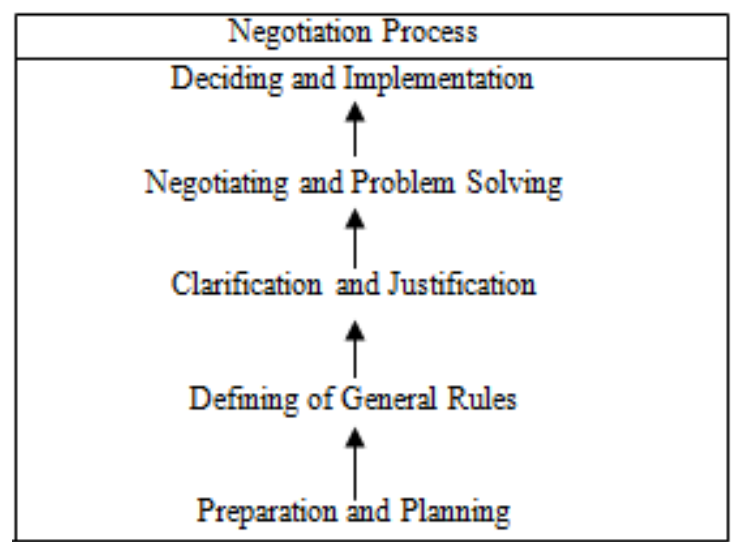

Source: Alo Liliweri, Prasangka dan Konflik, 2005, P.348.

- Preparation and Planning

Preparation towards anything who involving negotiation and its planning must be prepared. These thing consist of : time, place, agenda, and negotiation personnel.

The success of negotiation mostly determined by mature preparation and planning.

- Defining of General Rules

In this section, defining which is formulates the sense of issues or materialthat will be negotiated with the rules who cover it. These thing means to decide a mutual foundation for negotiation.

- Clarification and Justification

If there is sense of an issue in which not clear yet, then it would be possible to clarify and justify the things that will be negotiated.

- Negotiating and Problem Solving

Negotiation process would only be conducted if two parties are agreed and determining certain issue and make agenda to discuss it with the settlement steps at the same time.

- Deciding and Implementation

Product from negotiation process and the settlement continuously goes to the making decision (despite temporary decision and in steps) further implemented.

\subsection{Conflict}

Conflict literally comes from latin language "Confligere", which means collision. Furthermore, in the dictionary of the Collins Consice (1988:235), mentioned that conflict is "a struggle between opposing forces" meanwhile terminologically, conflict defined by Hugh Miall as :

"Conflict is intrinsic aspect and can't be denied in the process of social change. Conflict is an expression of heterogeneity, value of interest, and faith who appear as new formation which cause by social change who collide with inherited obstacles".

Another thing, K.J. Holsti defining conflict as :

"Disputes between states in order to obtain certain purposes such as expanding territory or defending territory, security, spirit, easy way for marketing area, prestige, alliance, world revolution, government overthrowed, unfriendly state, changing $\mathrm{n}$ the $\mathrm{UN}$, and etc".
Two definition above indicating that conflict can be happen where there are interest and demands who should be fulfilled, and in the process of demands fulfillment would be collide with another states interest and power. In the other words, if one state applying conflict behavior to gain interest, then the level of intension will be increased automatically as threat response until reaching certain level who pressing them.

In the historical perspective, conflict has been exist since the beginning of the humankind. Conflict phenomenom keeps occurring and even developing as the human activity has been increased nowadays without knowing time and place. In the other words, conflict can be occur whenever, wherever, and exist in every single community. Hugh Miall has classified conflict in two which is consist of conflict between states, and conflict between non-states. Conflict between states is conflict that occurred and involving two states or even more, meanwhile conflict non-states is the conflict who doesn't involving states, but internally happening inside the country of a state such as separatism, conflict between societies with government, and etc.

In the international relations context, it is natural that every state should interact each other. These interaction can be symmetrical and or a-symmetrical. Symmetrical can only be happen if the interaction is harmony and beneficial, meanwhile a-symmetrical interaction happens when only a party gets benefit and another parties lost their stuff. Thereby, every single state can't avoid the seeds of conflict with another state because of very various factors. Another one, the existing of different purpose and interest of each state being another factor who might be potentially present a conflict between states.

\subsection{Role of The Negotiation Substance}

According to the explanation above regarding the phenomenom of conflict and the cause, then surely every single party having faith that conflict must be faced and handled then solved. In many literatures, there are many ways to solve the conflict, one of the most is negotiation. These thing are running in the same way with definition of negotiation below :

"The process where interested parties resolve dispute agree upon courses of action, bargain for individual or collective advantage, and or attempt to craft outcomes which serve their mutual interest"

\section{Meanwhile Fred C. Ikle defining negotiation as :}

"Two elements must be present for negotiation take place there must be both comment interest and issues of conflict. Without comment interest there's nothing to negotiate for, without issues of conflict there's nothing to negotiation about".

Two definitions of negotiation above telling the sense that negotiation is an process of discussion to solve conflict. In this context any negotiator must be able and wanted to find best choices creatively to get a solution. Expected solution here is beneficial to both parties. To be able to catch that

\section{Volume 6 Issue 12, December 2017}




\section{International Journal of Science and Research (IJSR) \\ ISSN (Online): 2319-7064}

Index Copernicus Value (2016): 79.57 | Impact Factor (2015): 6.391

things, then both parties must be able to be volunteer and trust each other, also able to share mutual interest. When performing negotiation, It isn't to find the winner or the loser, because in every single negotiation it can resulting positive things through the chances of pointing out all the abilities that they have. These thing are running in the same way with the definition of negotiation that explained by Roger Fisher and William Ury :

"Negotiation is a basic means of getting what you want from others. It is back and forth communication designed to reach an agreement when you and other side have same interest that are shared and other that are opposed".

The sense of these definition is that in negotiating there are two-way direction of communication who arranged to achieve deals when two parties have the same or different interest. Principle before starting an discussion to solve the conflict is by positioning the place equally toward involved parties. Further, to reach the success in negotiation must having mutual view in seeing a solution.

\section{Conclusion}

According to the explanation about the role of negotiation in solving conflicts, then can be concluded as Conflict is historical product, and it has been the facts of life whether it is in the context between in a state or between states in the international context. Conflict appear as the result of chasing purposes in which colliding each other and covering any dimension in humanity, politic, economy, power, sovereignty territory, religion, energy, law, and etc. thereby, all of that can be solved with one of most solutions which is negotiation. Where, negotiation is an process of discussing where bidding each other to get a deal for the sake of obtaining purpose. Involved purpose is purpose based on mutual interest or different interest which is primary than negotiation who solving conflict by performing violence or military action that too risk when resulting a war as problem-solving where these earth can reduced the devastation.

\section{References}

[1] Patrice Lumumba. Negosiasi Dalam Hubungan Internasional. Yogyakarta : Graha Ilmu, 2013, P.1

[2] Patrice Lumumba. Negosiasi Dalam Hubungan Internasional. Yogyakarta : Graha Ilmu, 2013. P.2-3

[3] Alo Liliweri. Prasangka \& Konflik : Komunitas Lintas Budaya Masyarakat Multikultur. Yogyakarta: LKiS, 2005, P.345-346

[4] Mukhsin Jamil. Mengelola Konflik Membangun Damai : Teori, Strategi, dan Implementasi Resolusi Konflik. Semarang: WMC, 2007, P.17-18

[5] Tri Budi Satrio (Penerjemah). Resolusi Damai Konflik Kontemporer. Jakarta : PT Raja Grafindo Persada, 2000, P.7-8

[6] K.J. Holsti. Politik Internasional : Suatu Kerangka Analisis. Bandung : Bina Cipta, 1987, P.592

[7] Brian Frinch. 30 Minutes To Negotiate a Better Deal. Jakarta : PT Elex Media Komputindo, 2001, P.1

[8] Fred C, Ikle. Peace Prospect Between Palestine and Israel After Peace Agreed Agreement Hamas and al-Fatah. At http://publikasi.umy.ac.id/index.php/hi/article/viewfile/1 6391470 [accessed 22 Feb 2012]

[9] Roger Fisher \& William Ury. Getting Yes $2^{\text {nd }}$ Ed. London : Random House Business Books, 1995, P.XIIV

\section{Author Profile}

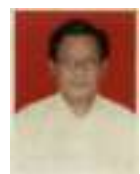

Patrice Lumumba received Bachelor degree in International Relations Department in Hasanuddin University, Makassar, South Sulawesi Province, Indonesia in 1985 and Master degree in American Studies at University of Indonesia, Java in 1997. He was involved in the study of Politic System and international affair of USA in 6 countries of USA which is Washington D.C, New York, Freeport Illinois, Phoenix Arizona, Seattle Washington, and San Francisco California. He stayed at Makassar working as lecturer in the social and politic sciences faculty in the international relations department.

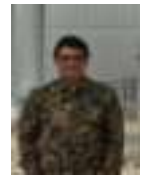

Husain Abdullah received Bachelor degree in International Relations Department in Hasanuddin University, Makassar, South Sulawesi Province, Indonesia in 1988 and Master degree in Communication Science Department in Hasanuddin University in 2009 also Ph.D degree in International Relations Department in Padjajaran University, Bandung. He stayed at Jakarta now working as spokesman of Vice President of Indonesia.

Volume 6 Issue 12, December 2017 www.ijsr.net 